\title{
A COMPARATIVE STUDY OF THE EFFICACY OF ANTIMICROBIAL COATED POLYGLACTIN 910 SUTURE VERSUS TRADITIONAL POLYGLACTIN 910 SUTURE IN SUBCUTICULAR SKIN SUTURING IN ELECTIVE INGUINAL HERNIA SURGERIES
}

\author{
Sharanabasappa S. Karbhari', Prachi M. Pujari², Umeshchandra D. $G^{3}$
}

1 Professor, Department of General Surgery, M. R. Medical College, Kalaburagi, Karnataka, India.

2Postgraduate Student, Department of General Surgery, M. R. Medical College, Kalaburagi, Karnataka, India.

3 Professor and HOD, Department of General Surgery, M. R. Medical College, Kalaburagi, Karnataka, India.

ABSTRACT

\section{BACKGROUND}

Surgical site infection (SSI) remains a pervasive problem in the surgical community. SSI leads to significant morbidity and mortality, also to longer hospital stays and greater health-care costs. Although several risk factors have been associated with SSI, contamination of suture material appears to be one of the most frequent causes. In view of the above, the present study is undertaken to evaluate the efficacy of new antibacterial coated Polyglactin 910 suture (Vicryl Plus) compared with a traditional Polyglactin 910 suture (Vicryl) in reducing surgical site infection.

\section{MATERIALS AND METHODS}

A total of 150 Patients undergoing elective inguinal hernia surgeries were studied during the study period from November 2016 to August 2018 at Basaveshwar Teaching and General Hospital attached to Dept of Surgery, Mahadevappa Rampure Medical College, Kalaburagi, Karnataka. Antimicrobial Coated Polyglactin 910 (Vicryl Plus) suture was used on 75 patients and Traditional Coated Polyglactin 910 (Vicryl) suture was used on 75 patients. The results of the study were tabulated and compared by using Chi square test and Fischer's Exact test to calculate P value. The sample size estimation was also done at conveniences.

\section{RESULTS}

In our study, statistically significant differences in reducing surgical site infection were noted on day 3, day 5, day 7 and day 14 between the two groups with $p$ value of $0.03,0.04,0.02$ and 0.028 respectively.

\section{CONCLUSION}

In the present study, Antimicrobial Coated Polyglactin 910 suture (Vicryl Plus) showed better results in reducing surgical site infection compared with the Traditional Coated Polyglactin 910 (Vicryl) suture.

\section{KEY WORDS}

Antibacterial Suture; Inguinal Hernia Repair; Surgical Site Infection.

HOW TO CITE THIS ARTICLE: Karbhari SS, Pujari PM, Umeshchandra DG. A comparative study of the efficacy of antimicrobial coated polyglactin 910 suture versus traditional polyglactin 910 suture in subcuticular skin suturing in elective inguinal hernia surgeries. J. Evolution Med. Dent. Sci. 2018;7(53):5576-5580, DOI: 10.14260/jemds/2018/1234

\section{BACKGROUND}

Surgical site infection (SSI) remains an immanent problem in the surgical community. The definition of surgical site infections (SSIs) according to the criteria developed by the Centers for Disease Control and Prevention include every SSI up to 30 days after the operation.(1)

According to the US Centers for Disease Control (CDC) National Nosocomial Infections Surveillance System, SSI is the third most frequent nosocomial infection in United States, accounting for $14-16 \%$ of infections among hospitalized patients and $38 \%$ of infections in surgical patients. $(1,2)$

SSI leads to substantial morbidity, mortality and also adds to longer hospital stays and greater health-care costs $(3,4)$

'Financial or Other Competing Interest': None.

Submission 13-11-2018, Peer Review 12-12-2018,

Acceptance 18-12-2018, Published 31-12-2018.

Corresponding Author:

Dr. Sharanabasappa S. Karbhari,

Professor

Department of General Surgery,

M. R. Medical College,

Kalaburagi,

Karnataka, India.

E-mail: sharankarbhari@gmail.com

DOI: $10.14260 /$ jemds/2018/1234

\section{(c) $($ ) $\$$}

Although several risk factors have been associated with SSI, $(1,2,5)$ bacterial contamination of suture material appears to be one of the most frequent causes. (6-8)

To reduce the risk of suture contamination, antimicrobial Polyglactin 910 suture coated with triclosan (Vicryl Plus) has been introduced. Triclosan is a broad spectrum antiseptic that has been widely used in humans for over 30 years. ${ }^{(9)}$

Surgical site infections after clean elective surgeries like inguinal hernia repair would increase the morbidity and also result in high cost of treatment.

Hence the present study is undertaken to evaluate the efficacy of new antibacterial coated Polyglactin 910 (Vicryl plus) suture compared with traditional coated Polyglactin 910 (Vicryl) suture in reducing surgical site infections in elective inguinal hernia surgery so as to reduce the use of antibiotics post operatively.

\section{Aims and Objectives}

1. To evaluate the efficacy of antibacterial coated Polyglactin 910 suture (Vicryl Plus) compared with a traditional Polyglactin 910 suture (Vicryl) in reducing surgical site infection.

2. Reducing antibiotic use postoperatively. 


\section{MATERIALS AND METHODS}

\section{Study Design}

It is a prospective, randomized, comparative, single-centre study.

The present study was carried out at Department of General Surgery, Basaveshwar Teaching and General Hospital attached to Mahadevappa Rampure Medical College, Kalaburagi, Karnataka from November 2016 to June 2018.

A total of 150 patients aged above 18 yrs. undergoing elective inguinal hernia repair were divided into two groups of 75 each Patients. Antimicrobial Coated Polyglactin 910 (Vicryl Plus) was used on 75 patients and Traditional Coated Polyglactin 910 (Vicryl) suture was used on 75 patients. The sample size estimation was also done at conveniences.

\section{Inclusion Criteria}

1. Patients undergoing elective inguinal hernia repair.

2. Patients aged above 18 years.

\section{Exclusion Criteria}

1. Immunocompromised individuals (diabetics, human immunodeficiency virus, bleeding disorders, patients on steroid therapy).

2. Pregnancy.

3. Known hypersensitivity to suture or its components based on past history.

4. Pre-existing surgical site infection.

5. Other surgeries like appendicectomy, exploratory laparotomy etc.

\section{Randomization}

Computer generated blocked random numbers will be used to assign the type of suture material used, that Is,

1. Group A - Antimicrobial Coated Polyglactin 910 (Vicryl Plus) suture.

2. Group B - Traditional Coated Polyglactin 910 (Vicryl) suture.

\section{Procedure}

In both the groups patients received same antibiotic dose that is Injection Taxim $1 \mathrm{~g}$ prior to surgery and same Inj. Taxim 1 gm IV BD was given for two days post operatively in all the patients. However, antibiotics were changed based on the severity of SSI, culture and sensitivity.

Patients in group A had wound closure using Vicryl plus and in group B, traditional Vicryl was used. The PostOperative care was similar for both the groups. Lichtenstein repair was done using prolene mesh followed by subcuticular skin suturing.

\section{Statistical Analysis}

The data obtained was entered in Microsoft Excel Spreadsheet. The categorical data was expressed in terms of rates, ratios and percentages. Continuous data was expressed as mean \pm standard deviation. The comparison of categorical data was carried out using chi-square test, Fisher's exact test. The comparison of continuous data was done using independent sample t test. A 'p' value of less than or equal to 0.05 was considered as statistically significant.

The database setup software was Oracle Clinical Version 4.1. All statistical analyses and summaries were performed using SAS ${ }^{\circledR}$ for Windows Version 9.1.3 on Enterprise Guide 4.1 (USA).

\section{Outcome}

The assessment of wound was carried out based on Southampton wound scoring system on post operative day three, five seven and fourteen.

Assessment of wound using Southampton Wound Scoring System 10

\begin{tabular}{|c|c|c|}
\hline \multicolumn{2}{|c|}{ Grades } & Appearance \\
\hline 0 & & Normal Healing \\
\hline \multirow{4}{*}{ I } & & $\begin{array}{l}\text { Normal Healing with Mild Bruising or } \\
\text { Erythema }\end{array}$ \\
\hline & A & Some Bruising \\
\hline & $\mathrm{B}$ & Considerable Bruising \\
\hline & $\mathrm{C}$ & Mild Erythema \\
\hline \multirow{5}{*}{ II } & & Erythema plus other Signs of Inflammation \\
\hline & A & At One Point \\
\hline & $\mathrm{B}$ & Around Sutures \\
\hline & $\mathrm{C}$ & Along Wound \\
\hline & $\mathrm{D}$ & Around Wound \\
\hline \multirow{5}{*}{ III } & & Clear or Haemo-Serous Discharge \\
\hline & A & At One Point Only $(<2 \mathrm{~cm})$ \\
\hline & $\mathrm{B}$ & Along Wound $(>2 \mathrm{~cm})$ \\
\hline & $\mathrm{C}$ & Large Volume \\
\hline & $\mathrm{D}$ & Prolonged (> 3 days) \\
\hline \multirow{3}{*}{ IV } & & Major Complications \\
\hline & A & At One Point $(<2 \mathrm{cms})$ \\
\hline & $\mathrm{B}$ & Along Wound $(>2 \mathrm{~cm})$ \\
\hline $\mathrm{V}$ & & $\begin{array}{c}\text { Deep Severe Wound Infection with or } \\
\text { without Tissue Breakdown; Haematoma } \\
\text { requiring Aspiration }\end{array}$ \\
\hline
\end{tabular}

\section{RESULTS}

The data obtained was tabulated and analysed. The final results and observations were tabulated as below.

\begin{tabular}{|c|c|c|c|c|}
\hline \multirow{2}{*}{$\begin{array}{c}\text { Age Group } \\
\text { (Years) }\end{array}$} & \multicolumn{2}{|c|}{ Group A (n=75) } & \multicolumn{2}{c|}{ Group B (n=75) } \\
\cline { 2 - 5 } & Number & Percentage & Number & Percentage \\
\hline 30 or less & 12 & 16 & 14 & 18.66 \\
\hline 31 to 45 & 18 & 24 & 7 & 9.33 \\
\hline 46 to 60 & 22 & 29.33 & 27 & 36 \\
\hline$>60$ & 23 & 30.66 & 27 & 36 \\
\hline Total & $\mathbf{7 5}$ & $\mathbf{1 0 0 . 0 0}$ & $\mathbf{7 5}$ & $\mathbf{1 0 0 . 0 0}$ \\
\hline \multicolumn{6}{|c|}{ Table 1. Age Distribution } \\
\hline
\end{tabular}

$\mathrm{p}$ value $=0.12$.

In the present study most of the patients in group A were aged be $>60$ years (30.66\%) compared to $36 \%$ each between 46-60 years and $>60$ years in group B. However, the difference was statistically not significant $(\mathrm{p}=0.12)$.

\begin{tabular}{|c|c|c|c|c|c|}
\hline \multirow{2}{*}{ Variables } & Group A (n=75) & Group B (n=75) & \multirow{2}{*}{ p value } \\
\cline { 2 - 5 } & Mean & SD & Mean & SD & \\
\hline Age (Years) & 50.33 & 16.44 & 52.68 & 16.85 & 0.38 \\
\hline \multicolumn{6}{|c|}{ Table 2. Mean Age } \\
\hline
\end{tabular}

In this study the mean age in group A was $50.33 \pm 16.44$ years compared to $52.68 \pm 16.85$ years in group B but the difference was statistically not significant $(\mathrm{p}=0.38)$. 


\begin{tabular}{|c|c|c|c|c|c|}
\hline \multirow[t]{2}{*}{ Variables } & \multicolumn{2}{|c|}{$\begin{array}{l}\text { Group A } \\
(n=75)\end{array}$} & \multicolumn{2}{|c|}{$\begin{array}{l}\text { Group B } \\
(n=75)\end{array}$} & \multirow{2}{*}{$\begin{array}{c}\text { p } \\
\text { Value }\end{array}$} \\
\hline & Mean & SD & Mean & SD & \\
\hline $\begin{array}{l}\text { Pulse Rate } \\
\text { (/Minute) }\end{array}$ & 79.48 & 8.54 & 78.57 & 6 & 0.45 \\
\hline SBP (mmHg) & 119.06 & 9.03 & 119.46 & 8.03 & 0.77 \\
\hline DBP (mmHg) & 74.93 & 8.69 & 76.88 & 8.74 & 0.17 \\
\hline $\begin{array}{c}\text { Respiratory Rate } \\
\text { (/Minute) }\end{array}$ & 24.2 & 1.88 & 23.81 & 2.22 & 0.24 \\
\hline
\end{tabular}

Comparison of mean pulse rate, systolic and diastolic blood pressure and respiratory rate. It was observed that, these variables were comparable in group A and B ( $p>0.050)$.

\begin{tabular}{|c|c|c|c|c|}
\hline \multirow{2}{*}{ SSI Grade (n=75) } & \multicolumn{2}{c|}{ Group B (n=75) } \\
\cline { 2 - 5 } & Number & Percentage & Number & Percentage \\
\hline IA & 3 & 4 & 7 & 9.33 \\
IC & 1 & 1.33 & 7 & 9.33 \\
\hline Absent & 71 & 94.66 & 61 & 81.33 \\
\hline Total & $\mathbf{7 5}$ & $\mathbf{1 0 0 . 0 0}$ & $\mathbf{7 5}$ & $\mathbf{1 0 0 . 0 0}$ \\
\hline Table 4. Surgical Site Infection on Post Operative Day 3 \\
\hline
\end{tabular}

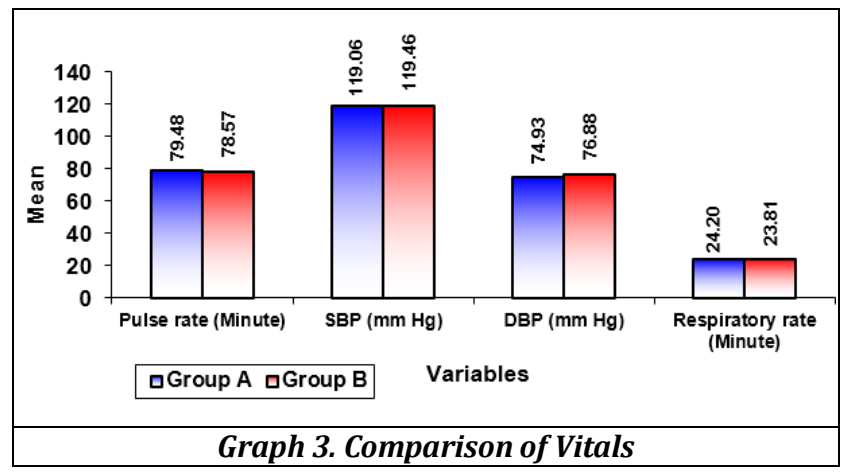

In the present study, on post operative day three, grade IA and IC SSI was noted in $4 \%$ and $1.33 \%$ respectively in group A compared to IA $(9.33 \%)$ and IC $(9.33 \%)$ in group B with statistically significant difference ( $p$ value $=0.032$ )

\begin{tabular}{|c|c|c|c|c|}
\hline \multirow{2}{*}{$\begin{array}{c}\text { SSI } \\
\text { Grade }\end{array}$} & \multicolumn{2}{|c|}{ Group A (n=75) } & \multicolumn{2}{c|}{ Group B (n=75) } \\
\cline { 2 - 5 } & Number & Percentage & Number & Percentage \\
\hline IA & 2 & 2.66 & 5 & 6.66 \\
\hline IC & 1 & 1.33 & 4 & 5.33 \\
IIC & 0 & 0 & 3 & 4 \\
\hline IIIB & 0 & 0 & 2 & 2.66 \\
IIIC & 0 & 0 & 1 & 1.33 \\
\hline Absent & 72 & 96 & 60 & 80 \\
\hline Total & $\mathbf{7 5}$ & $\mathbf{1 0 0 . 0 0}$ & $\mathbf{7 5}$ & $\mathbf{1 0 0 . 0 0}$ \\
\hline Table 5. Surgical Site Infection on Post Operative Day 5 \\
\hline p value= 0.042
\end{tabular}

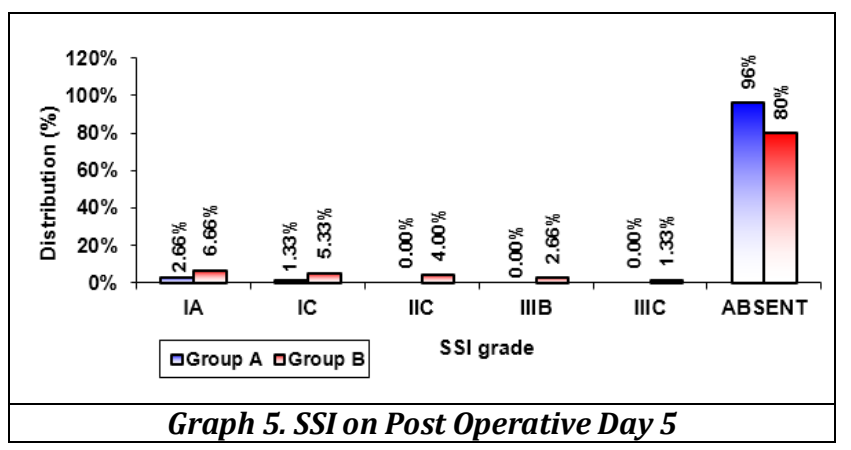

In this study, on post operative day five, among the patients with group A, grade IA (2.66\%) and IC (1.33\%) SSI was noted while in group B grade IA (6.66\%), IC (5.33\%), IIC (4\%) and IIIB (2.66\%) and IIIC (1.33\%) were present. A statistically significant difference was noted, $(p=0.042)$.

\begin{tabular}{|c|c|c|c|c|}
\hline \multirow{2}{*}{ SSI Grade } & \multicolumn{2}{|c|}{ Group A (n=75) } & \multicolumn{2}{c|}{ Group B (n=75) } \\
\cline { 2 - 5 } & Number & Percentage & Number & Percentage \\
\hline IA & 1 & 1.33 & 2 & 2.66 \\
\hline IC & 0 & 0 & 2 & 2.66 \\
\hline IIIA & 0 & 0 & 5 & 6.66 \\
IIIB & 1 & 1.33 & 3 & 4 \\
\hline IIIC & 0 & 0 & 1 & 1.33 \\
\hline Absent & 73 & 97.33 & 62 & 82.66 \\
\hline Total & 75 & 100.00 & 75 & 100.00 \\
\hline Table 6. Surgical Site Infection on Post Operative Day 7 \\
\hline
\end{tabular}
$\mathrm{p}$ value $=0.02$.

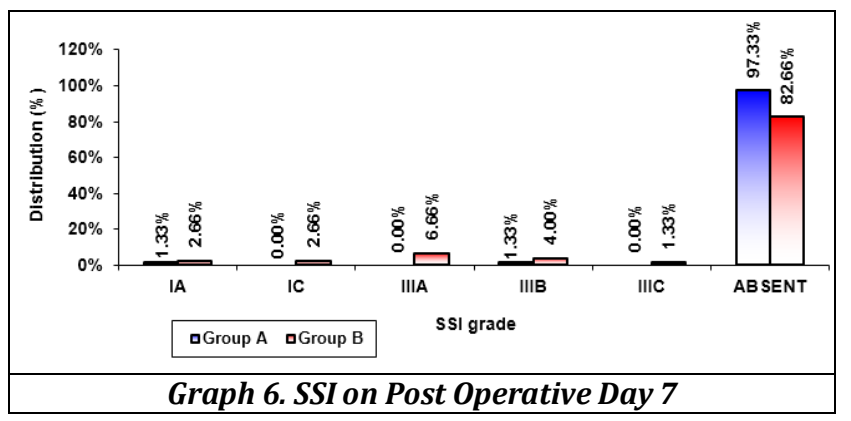

In the present study on post operative day seven, grade IA and IIIB were present in $1.33 \%$ each among the patients who belonged to group $A$. In group $B$, grade IA $(2.66 \%)$, IC $(2.66 \%)$, IIIA (6.66\%), IIB (4\%) and IIIC (1.33\%) were noted. $(\mathrm{p}=0.02)$.

\begin{tabular}{|c|c|c|c|c|}
\hline \multirow{2}{*}{ SSI Grade } & \multicolumn{2}{|c|}{ Group A (n=75) } & \multicolumn{2}{c|}{ Group B (n=75) } \\
\cline { 2 - 5 } & Number & Percentage & Number & Percentage \\
\hline IIC & 0 & 0.00 & 2 & 2.66 \\
\hline IIIA & 0 & 0.00 & 4 & 5.33 \\
\hline Absent & 75 & 100.00 & 69 & 92 \\
\hline Total & $\mathbf{7 5}$ & $\mathbf{1 0 0 . 0 0}$ & $\mathbf{7 5}$ & $\mathbf{1 0 0 . 0 0}$ \\
\hline
\end{tabular}

Table 7. Surgical Site Infection on Post Operative Day 14 $\mathrm{p}$ value $=0.028$.

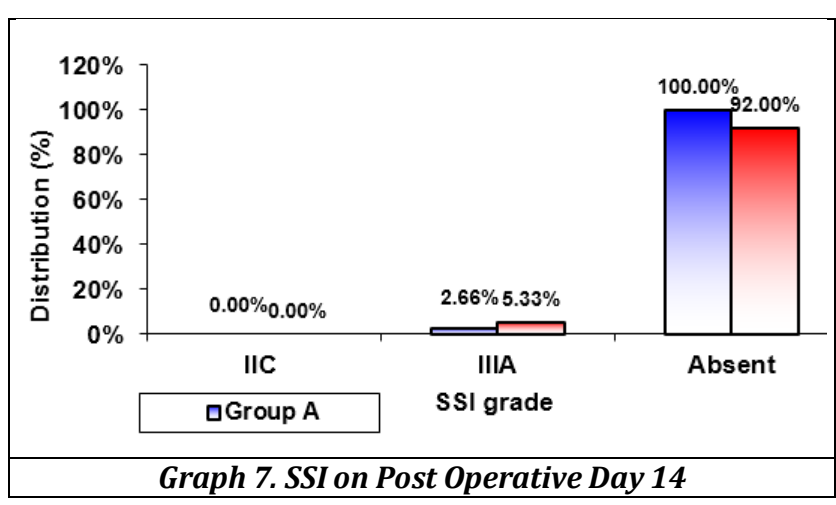

In this study, no SSI were noted in group A patients while, grade IIC $(2.66 \%)$ and grade IIIA $(5.33 \%)$ of patients in group $B$ were noted with statistically significant ( $p$ value $=0.028$ ). 


\begin{tabular}{|c|c|c|c|c|c|}
\hline \multirow{2}{*}{ Variables } & \multicolumn{2}{|c|}{$\begin{array}{c}\text { Group A } \\
(\mathbf{n = 7 5 )}\end{array}$} & \multicolumn{2}{c|}{$\begin{array}{c}\text { Group B } \\
(\mathbf{n = 7 5})\end{array}$} & \multirow{2}{*}{ p value } \\
\cline { 2 - 5 } & Mean & SD & Mean & SD & \\
\hline Duration (Days) & 2.01 & 0.11 & 2.18 & 0.56 & 0.01 \\
\hline \multicolumn{3}{|c|}{ Table 8. Duration of Antibiotic Administration } \\
\hline
\end{tabular}

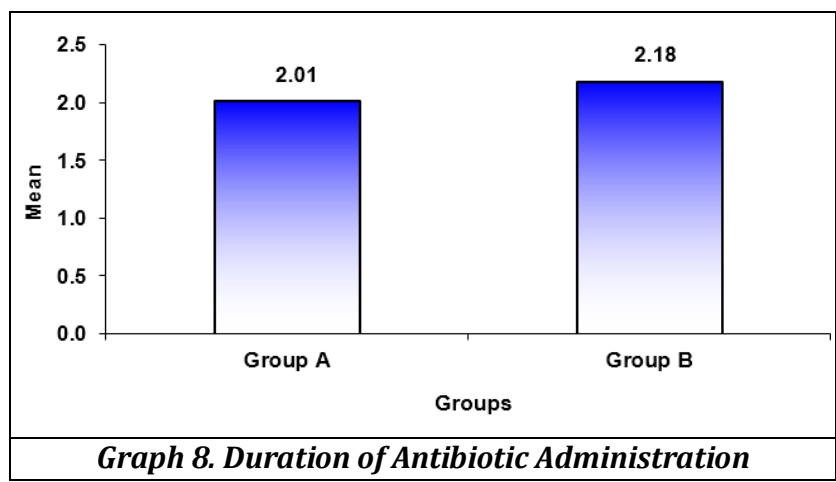

In the present study the mean duration of antibiotic administration in group A and B was comparable (2.01 \pm 0.11 compared to $2.18 \pm 0.56$ days; with statistically significant difference between the two groups $p$ value $=0.01$.

\section{DISCUSSION}

Surgical site infections (SSI) continue to be a major problem, despite the advances made in asepsis, antimicrobial drugs, and sterilization and operative techniques.(11) SSIs can progress from local to systemic infection, increasing mortality and morbidity risk associated with longer hospital stay and higher healthcare costs.

The most widely recognized definition of infection is devised and adopted by the Center for Disease Control and Prevention.(12) An SSI is defined as an infection occurring within 30 days of surgery that meets the following criteria-

1. The diagnosis consists of the infection of an anatomic plane by one of the following manifestations: collection, inflammatory signs (Pain, Oedema, Tenderness, Redness), dehiscence, or positive culture.

2. Classification according to the anatomic plane as

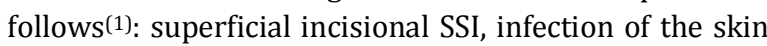
and subcutaneous tissue; deep incisional SSI, infection of the deep soft tissue (Fascia and Muscles); and organ/space SSI, infection of the organ/space.

A system of classification for surgical wounds that is based on the degree of microbial contamination was developed by the US National Research Council group in 1964.(13) Four wound classes with an increasing risk of SSI were described: clean, clean-contaminated, contaminated, and dirty.

According to the National Nosocomial Infections Surveillance System, the most frequently isolated pathogens from SSI are Staphylococcus aureus (20\%) and coagulasenegative staphylococci.(1)

Multiple risk factors for the development(14-15) of poor wound healing have been identified. Although patient-related factors such as sex, age, body mass index (BMI), complications, prior surgical procedure and lifestyle-related factors are difficult to modify, the identification of strategies for reducing wound contamination can help decrease the risk of SSIs. In addition to above factors the presence of suture material in wounds increases the susceptibility of the tissue to infection. $(16,17)$

A suture is a biomaterial device, natural or synthetic, used to approximate tissues together following separation by surgery or trauma. Different methods for mechanical wound closure are sutures, staples, tape and adhesives of which sutures are the most widely used materials in wound closure.

As a result of capillary action of suture materials, they can serve as vehicles for mechanical transport of bacteria into the surgical incision.(16) Sutures can lead to surgical wound contamination due to bacterial colonization and adherence. Only 100 colony-forming units (CFU)/mg are necessary to produce infection in presence of suture materials. (18) Thus in an attempt to reduce surgical site infection, sutures impregnated with antibacterial agents have been developed.

The most common organisms responsible for SSI include Staphylococcus aureus, Staphylococcus epidermidis, methicillin-resistant S. aureus (MRSA), and methicillinresistant S. epidermidis (MRSE).(1,19)

Potential antiseptics for coating surfaces include chlorhexidine, polyhexamethylene biguanide (PHMB), octenidine and triclosan. Compared to antibiotics, antiseptics have multiple targets and true 'resistance' is rare. (20) The only substance being used to impregnate suture is Triclosan.

Vicryl Plus was approved for clinical used by the US Food and Drug Administration (US FDA) since 2002.(21) Triclosan has been widely used as a safe and effective antimicrobial agent for more than 30 years in consumer and health-care products, including toothpaste, soap, hand hygiene products, and surgical scrubs. ${ }^{(22)}$

Coated polyglactin 910 suture with triclosan (Vicryl Plus) was impregnated in suture material with antibacterial activity against the most common putative pathogens that cause SSI. It has been proved to be effective against both methicillin-sensitive and methicillin-resistant S. aureus (MSSA, MRSA); furthermore, triclosan-resistant populations have not been encountered.(23)

Furthermore, triclosan has been proved to be nontoxic and does not have effect on tissue reaction, healing response or the absorption profile of coated polyglactin 910 suture with triclosan (Vicryl Plus), compared to the traditional polyglactin 910 suture (Vicryl).(24)

Galal and El-Hindawy(25) reported a prospective, randomized, double-blind study that showed that triclosancoated polyglactin 910 reduced the incidence of SSIs from $15 \%$ to $7 \%$. In a sternal wound closure study, the rate of SSI after the use of VICRYL Plus was found to be 0 of $103(0 \%)$ versus 24 of $376(6 \%)$ after the use of conventional Vicryl.(26)

Surgical site infection following elective hernia repair which is classified under clean surgery increases the morbidity, cost and long duration of hospital stay. Hence the use of antimicrobial coated Vicryl suture significantly contributes by reducing surgical site infection.

\section{CONCLUSION}

Based on the findings of this study, it may be concluded that the efficacy of new antibacterial coated suture (Vicryl Plus) is better than traditional coated suture (Vicryl) in reducing surgical site infection among the patients undergoing elective inguinal hernia repair. 


\section{REFERENCES}

[1] Mangram AJ, Horan TC, Pearson ML, et al. Guideline for prevention of surgical site infection, 1999. Centers for Disease Control and Prevention (CDC) Hospital Infection Control Practices Advisory Committee. Am J Infect Control 1999;27(2):97-134.

[2] Owens CD, Stoessel K. Surgical site Infections: epidemiology, microbiology and prevention. J hosp Infect 2008;70(Suppl 2):3-10.

[3] Coello R, Charlett A, Wilson J, et al. Adverse impact of surgical site infections in English hospitals. J Hosp Infect 2005;60(2):93-103.

[4] Kirklan KB, Briggs JP, Trivette SL, et al. The impact of surgical site infections in the 1990s: attributable mortality, excess length of hospitalization and extra costs. Infect Control Hosp Epidemiol 1999;20(11):725-30.

[5] Fry DE. Fifty ways to cause surgical site infections. Surg Infect (Larchmt) 2011;12(6):497-500.

[6] Alexander JW, Kaplan JZ, Altemeier WA. Role of suture materials in the development of wound infection. Ann Surg 1967;165(2):192-9.

[7] Hranjec T, Swenson BR, Sawyer RG. Surgical site infection prevention: how we do it. Surg Infect (Larchmt) 2010;11(3):289-94.

[8] Masini BD, Stinner DJ, Waterman SM, et al. Bacterial adherence to suture materials. J Surg Educ 2011;68(2):101-4.

[9] Bhargava HN, Leonard PA. Triclosan: applications and safety. Am J Infect Control 1996;24(3):209-18.

[10] Williams NS, Bulstrode CJK, O'Connel PR. Bailey and Love's Short practice of surgery. 26 th edn. CRC Press 2013: p. 54.

[11] Nandi PL, Rajan SS, Mak KC, et al. Surgical wound infection. HKMJ 1999;5(1):82-6.

[12] Horan TC, Gaynes RP, Martone WJ, et al. CDC definitions of nosocomial surgical site infections, 1992: a modification of CDC definitions of surgical wound infections. Infect Control Hosp Epidemiol 1992;13(10):606-8.

[13] Berard F, Gandon J. Postoperative wound infections: the influence of ultraviolet irradiation of the operating room and of various other factors. Ann Surg 1964;160(Suppl 2):1-192.

[14] National Nosocomial Infections Surveillance System. National Nosocomial Infections Surveillance (NNIS) System report, data summary from January 1992 through June 2004, issued October 2004. Am J Infect Control 2004;32(8):470-85.

[15] Engemann JJ, Carmeli Y, Cosgrove SE, et al. Adverse and economic outcomes attributable to methicillin resistance among patients with Staphylococcus aureus surgical site infection. Clin Infect Dis 2003;36(5):5928.
[16] Katz S, Izhar M, Mirelman D. Bacterial adherence to surgical sutures: a possible factor in suture induced infection. Ann Surg 1981;194(1):35-41.

[17] Edlich RF, Panek PH, Rodeheaver GT, et al. Physical and chemical configuration of sutures in the development of surgical infection. Ann Surg 1973;177(6):679-88.

[18] Gomez-Alonso A, Garcia-Criado FJ, Parreno-Manchado FC, et al. Study of the efficacy of Coated VICRYL Plus Antibacterial suture (coated Polyglactin 910 suture with Triclosan) in two animal models of general surgery. J Infect 2007;54(1):82-8.

[19] Rothenburger S, Spangler D, Bhende S, et al. In vitro antibacterial evaluation of coated Vicryl* Plus antibacterial suture (coated polyglactin 910 with triclosan) using zone of inhibition assays. Surg Infect (Larchmt) 2002;3(Suppl 1):S79-S87.

[20] Leaper D, McBain AJ, Kramer A, et al. Healthcare associated infection: novel strategies and antimicrobial implants to prevent surgical site infection. Ann R Coll Surg Engl 2010;92(6):453-8.

[21] Rozzelle CJ, Leonardo J, Li V. Antimicrobial suture wound closure for cerebrospinal fluid shunt surgery: a prospective, double-blinded, randomized controlled trial. J Neurosurg Pediatr 2008;2(2):111-7.

[22] Escalada MG, Harwood JL, Maillard JY, et al. Triclosan inhibition of fatty acid synthesis and its effect on growth of Escherichia coli and Pseudomonas aeruginosa. J Antimicrob Chemother 2005;55(6):87982.

[23] Gilbert P, McBain AJ. Literature-based evaluation of the potential risks associated with impregnation of medical devices and implants with triclosan. Surg Infect (Larchmt) 2002;3(Suppl 1):S55-S63.

[24] Barbolt TA. Chemistry and safety of triclosan and its use as an antibacterial coating on coated VICRYL* Plus antibacterial suture (coated polyglactin 910 with triclosan). Surg Infect (Larchmt) 2002;3(Suppl 1):S45S53.

[25] Galal I, El-Hindawy K. Impact of using triclosanantibacterial sutures on incidence of surgical site infection. Am J Surg 2011;202(2):133-8.

[26] Fleck T, Moidl R, Blacky A, et al. Triclosan-coated sutures for the reduction of sternal wound infections: economic considerations. Ann Thorac Surg 2007;84(1):232-6. 